\title{
Stratospheric role in interdecadal changes of El Niño impacts over Europe
}

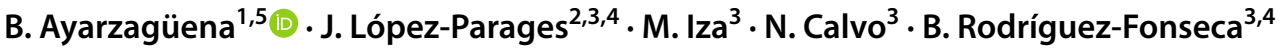

Received: 6 September 2017 / Accepted: 20 March 2018 / Published online: 2 April 2018

(c) The Author(s) 2018

\begin{abstract}
The European precipitation response to El Niño (EN) has been found to present interdecadal changes, with alternated periods of important or negligible EN impact in late winter. These periods are associated with opposite phases of multi-decadal sea surface temperature (SST) variability, which modifies the tropospheric background and EN teleconnections. In addition, other studies have shown how SST anomalies in the equatorial Pacific, and in particular, the location of the largest anomalous SST, modulate the stratospheric response to EN. Nevertheless, the role of the stratosphere on the stationarity of EN response has not been investigated in detail so far. Using reanalysis data, we present a comprehensive study of EN teleconnections to Europe including the role of the ocean background and the stratosphere in the stationarity of the signal. The results reveal multidecadal variability in the location of EN-related SST anomalies that determines different teleconnections. In periods with relevant precipitation signal over Europe, the EN SST pattern resembles Eastern Pacific EN and the stratospheric pathway plays a key role in transmitting the signal to Europe in February, together with two tropospheric wavetrains that transmit the signal in February and April. Conversely, the stratospheric pathway is not detected in periods with a weak EN impact on European precipitation, corresponding to EN-related SST anomalies primarily located over the central Pacific. SST mean state and its associated atmospheric background control the location of EN-related SST anomalies in different periods and modulate the establishment of the aforementioned stratospheric pathway of EN teleconnection to Europe too.
\end{abstract}

Keywords El Niño $\cdot$ Stratospheric pathway $\cdot$ Multidecadal variability $\cdot$ European precipitation

\section{Introduction}

El Niño-Southern Oscillation (ENSO) is the most important phenomenon from seasonal to interannual timescales of the oceanic-atmospheric climate variability. It originates in the tropical Pacific and its effects extend to other basins

\section{B. Ayarzagüena}

bayarzag@ucm.es

1 College of Engineering, Mathematics and Physical Sciences, University of Exeter, Exeter, UK

2 Dpto. di Scienze Ambientali, Informatica e Statistica, Ca Foscari University of Venice, Venice, Italy

3 Dpto. Fisica de la Tierra y Astrofísica, Facultad de CC. Físicas, Universidad Complutense de Madrid, Madrid, Spain

4 Instituto de Geociencias UCM-CSIC, Madrid, Spain

5 Present Address: Dpto. Fisica de la Tierra y Astrofísica, Facultad de CC. Físicas, Universidad Complutense de Madrid, Ciudad Universitaria, 28040 Madrid, Spain and regions, including Europe (Peixoto and Oort 1992). The ENSO signal on European weather resembles a North Atlantic Oscillation (NAO) pattern and peaks in late winterspring (e.g.: Moron and Gouirand 2003). The tropical signal reaches Europe through different pathways along the troposphere and stratosphere (e.g.: Brönnimann 2007 and references therein). The tropospheric pathway itself includes four documented different tracks (García-Serrano et al. 2017). One of the most recognized tracks is associated with changes in the non-divergent (or rotational) flow and involves a North Pacific-North Atlantic connection through the excitation of a tropical forced wavetrain from the Pacific (describing the Tropical Northern Hemisphere pattern; hereinafter TNH) that propagates into the North Atlantic (e.g.: Brönnimann 2007). Another well-known tropospheric pathway is through changes in the divergent flow, which is established in the tropics linking Atlantic and Pacific throughout the Walker cell and influencing the North Atlantic area by modifying the Atlantic Hadley cell (e.g.: Wang 2002; Ham et al. 2014). Regarding the stratospheric connection, it consists 
of a two-step mechanism. El Niño (EN) signal reaches the stratosphere through the intensification of the upward propagation of stationary waves (in particular, wavenumber 1 component) resulting from the strengthening of the Aleutian low, as part of the Pacific North American (PNA)-like pattern in the troposphere (e.g.: Taguchi and Hartmann 2006; García-Herrera et al. 2006; Garfinkel et al. 2008). Upward planetary waves dissipate in the stratosphere, warming the polar stratosphere and weakening the polar vortex. As a second step, the EN-induced polar stratospheric anomalies descend reaching the troposphere in late winter (e.g.: Manzini et al. 2006) and inducing a negative NAO phase (Bell et al. 2009; Cagnazzo and Manzini 2009; Ineson and Scaife 2009; Herceg-Bulic et al. 2017). Most of these studies also showed that the occurrence of a major stratospheric warming (MSW) is essential for the establishment of the aforementioned downward propagation of the EN-induced stratospheric anomalies.

Nonetheless, this stratospheric pathway of impact over Europe is only found for canonical EN winters, when the largest SST anomalies are located in the Eastern Pacific, EP EN. In contrast, for centrally located EN events, Central Pacific EN (CP EN), such stratospheric pathway is missing (e.g.: Zubiaurre and Calvo 2012; Sung et al. 2014; Iza and Calvo 2015; Calvo et al. 2017). Indeed, the tropospheric teleconnections generated by these two types of events are different, in particular, the change in the strength of the Aleutian low, which is, in general, stronger in winter for EP EN than CP EN (Yu and Kim 2011). This would explain the existence or not of the stratospheric pathway depending on the EN type. The previous statements have been derived assuming that EN teleconnections to Europe for both types of EN are not modulated by the oceanic mean state, but very recent studies have given evidence that this assumption should be rejected at least for the tropospheric teleconnections. By means of sensitivity experiments with an atmospheric general circulation model, López-Parages et al. (2016a) demonstrated that the remote impact of EP EN events on Europe is enhanced when the tropical Pacific SST mean state is warmer and the North Atlantic SST is colder than usual. A change in the upper tropospheric flow and consequently, the propagation of Rossby wavetrains in the troposphere was found to be relevant for these differences in the EP EN impact on Europe. These authors did not address the modulation of the stratospheric part of the teleconnection associated with the two EN types though.

In agreement with the modulation of the EN teleconnections by the oceanic mean state, some authors have found that the European response to EN has changed with time across the twentieth century regardless of the type of EN (e.g.: Mariotti et al. 2002; López-Parages and RodríguezFonseca 2012; López-Parages et al. 2015). In fact, LópezParages et al. 2015 (LP2015 hereafter) analyzed in detail the multi-decadal modulation of ENSO teleconnection to Europe based on the first mode of co-variability of European precipitation and tropical SST in observations and a long-term pre-industrial simulation. LP2015 identified periods in which ENSO has a significant impact on the European precipitation and other periods in which the ENSO effects over Europe are almost negligible. The origin of the changing ENSO impact on Euro-Atlantic precipitation was again identified to be the multi-decadal variability of the SST. Similar results were found in long-term pre-industrial simulations for an ensemble of 18 models (López-Parages et al. 2016b). Since multi-decadal changes in SST lead to changes in the upper tropospheric flow, it would be expected that the stratospheric pathway also becomes affected, but all mentioned work only focused on the modulation of the tropospheric pathway. Only Rodríguez-Fonseca et al. (2016) in their Fig. 3 gave a first hint that the first co-variability mode of European precipitation and tropical SST for periods with a strong ENSO significant impact on Europe might be associated with perturbations in the polar stratosphere, but not for periods with a negligible European response to ENSO. However, these authors did not explore the underlying mechanisms explaining the modifications in the stratospheric pathway between different periods or the effects of multi-decadal variability of the SST on the stratospheric mean state.

As mentioned before, the multi-decadal modulation of the ENSO teleconnection to Europe through the stratosphere has not been examined in detail yet, probably because it has been only recently that the very low-frequency variability of the polar stratosphere has been investigated (e.g.: Schimanke et al. 2011; Reichler et al. 2012; Woo et al. 2015; Omrani et al. 2016) and there is still a lot of uncertainty in this topic. The analysis of multi-decadal changes in the ENSO-related stratospheric teleconnection would be extremely relevant since these changes might contribute to the interdecadal variability of EN signal over Europe and it would then help to provide a complete picture of the non-stationary ENSO impacts over this area.

Therefore, in this study, we examine the interdecadal variability of the pathways of EN teleconnection to Europe in reanalysis data focusing on determining whether the EN teleconnection through the stratosphere contributes, at least partially, to the differences in the European precipitation response detected in previous studies. To do that, we analyze the tropospheric forcing, the state of the polar stratosphere and the possible downward propagation of the stratospheric signal associated with EN events for those periods with different European precipitation response to EN in late winter. Additionally, we examine interdecadal changes in the oceanic mean state and the tropospheric and stratospheric background in the different periods to investigate the potential reasons that lead to a change in the EN-related stratospheric 
teleconnection to Europe. Thus, the analysis constitutes a comprehensive study where we reconcile the knowledge on EN stratospheric and tropospheric pathways to Europe at different time scales and the influence of the oceanic mean state on them. We focus only on EN events to avoid some issues related to asymmetries between El Niño and La Niña (LN) and because the signal of EN in the stratosphere is usually stronger than that of LN (Mitchell et al. 2011).

The paper is organized as follows. The data and methodology are presented in Sect. 2. Section 3 describes the results related to the EN-European precipitation connection through the stratosphere in different periods. The background conditions in the ocean, troposphere and stratosphere for periods with a different EN signal in Europe are analyzed in Sect. 4. Finally, a summary with the most relevant conclusions and a short discussion are presented in Sect. 5 .

\section{Data and methodology}

In this study, monthly mean sea surface temperature (SST) data is taken from the Hadley Centre Sea Ice and Sea Surface Temperature data set (HadISST1) with a $1^{\circ} \times 1^{\circ}$ resolution (Rayner et al. 2003). The atmospheric data comes from the National Center for Environmental Prediction/National Center for Atmospheric Research (NCEP/NCAR) reanalysis in a $2.5^{\circ}$ latitude $\mathrm{x} 2.5^{\circ}$ longitude grid (Kalnay et al. 1996). Precipitation data corresponds to the University of Delaware global land precipitation dataset with a horizontal resolution of $0.5^{\circ} \times 0.5^{\circ}$ (Willmott and Matsuura 2001). Oceanic and atmospheric data covers the period from 1948 to 2012 except for the precipitation dataset that only extends until 2010. Anomalies are computed based on the climatology of all available years and linearly detrended in each grid point and for the single month/season to avoid the effects of anthropogenic influence. This detrending procedure is one of the most common approaches to avoid anthropogenic effects and some verifications have been made to ensure that it is acceptable for the purposes of our study. In fact, we have verified that data shows a persistent trend of the same sign along the whole period and there are not large discontinuities surrounding the starting time of the assimilation of satellite data by the reanalysis.

Following LP2015 we distinguish two sub-periods based on the effects of El Niño on late winter European rainfall and in particular, on the correlation between EN3.4 index $\left(5^{\circ} \mathrm{S}\right.$ $5^{\circ} \mathrm{N}, 120^{\circ} \mathrm{W}-170^{\circ} \mathrm{W}$ ) and the principal component of the first variability mode of the Euro-Mediterranean precipitation in February-March-April (FMA) (see LP2015 for more details). Their results show that the period from 1965 to 1984 is characterized by a strong response of the European precipitation to ENSO in FMA and shows a statistically significant positive correlation between the mentioned oceanic and precipitation time series. Hereafter, this positive period is referred as the P period. Conversely, the impact of ENSO on the European rainfall is weak from 1949 to 1964 and from 2003 to 2008 and the aforementioned time series show a low negative correlation. These periods are analyzed jointly and denoted as the $\mathrm{N}$ period.

Our analysis is performed by creating composite maps of different variables for $\mathrm{EN}$ events in the $\mathrm{P}$ and $\mathrm{N}$ periods. The EN events have been identified when the standardized EN3.4 index in December-January-February exceeds 0.5, finding 6 events in the $\mathrm{N}$ period and 8 events in the $\mathrm{P}$ period (Table 1). MSWs have been identified by imposing the reversal of the zonal mean zonal wind at $60^{\circ} \mathrm{N}$ and $10 \mathrm{hPa}$ (Butler et al. 2015). The statistical significance of our results has been computed with a Monte-Carlo test with 500 permutations and it will be given at the $90 \%$ confidence level (considering the low number of events in each sample). Please note that our results do not change when using more recent reanalyses such as JRA-55 with a higher resolution and a better assimilation data scheme than NCEP/NCAR reanalysis. Being the results similar, we have preferred to use NCEP/NCAR reanalysis as it covers a longer time period than the rest of the modern reanalysis.

\section{Stratospheric pathway of EN teleconnection to Europe in different periods}

First, we identify the EN signal on the FMA European weather in the $\mathrm{P}$ and $\mathrm{N}$ periods defined in LP2015. This is presented in Fig. 1 that shows composites of precipitation and sea level pressure (SLP) anomalies in FMA for EN events during $\mathrm{P}$ and $\mathrm{N}$ periods. As expected, the precipitation pattern shows differences between both periods (Fig. 1a, c). Whereas the FMA precipitation pattern for EN events in the P period presents statistically significant positive anomalies over most of Europe (Fig. 1a), the statistically significant anomalies of the pattern for the $\mathrm{N}$ period are of

Table 1 List of EN winters in $\mathrm{P}$ and $\mathrm{N}$ period

\begin{tabular}{ll}
\hline P Period (1965-1984) & N period (1949-1964; 2003-2008) \\
\hline $1965-1966 *(E P)$ & $1951-1952 *$ \\
$1968-1969^{*}(\mathrm{CP})$ & $1957-1958^{*}(\mathrm{EP})$ \\
$1969-1970 *$ & $1963-1964$ \\
$1972-1973 *(\mathrm{EP})$ & $2002-2003 *(\mathrm{CP})$ \\
$1976-1977 *(\mathrm{EP})$ & $2004-2005(\mathrm{CP})$ \\
$1977-1978$ & $2006-2007 *(\mathrm{CP})$ \\
$1979-1980 *$ & \\
$1982-1983(\mathrm{EP})$ & \\
\hline
\end{tabular}

Asterisk denotes winters with major stratospheric warming occurrence and the type of EN, Eastern Pacific (EP) or Central Pacific $(\mathrm{CP})$, is found in brackets 


\section{Precipitation}
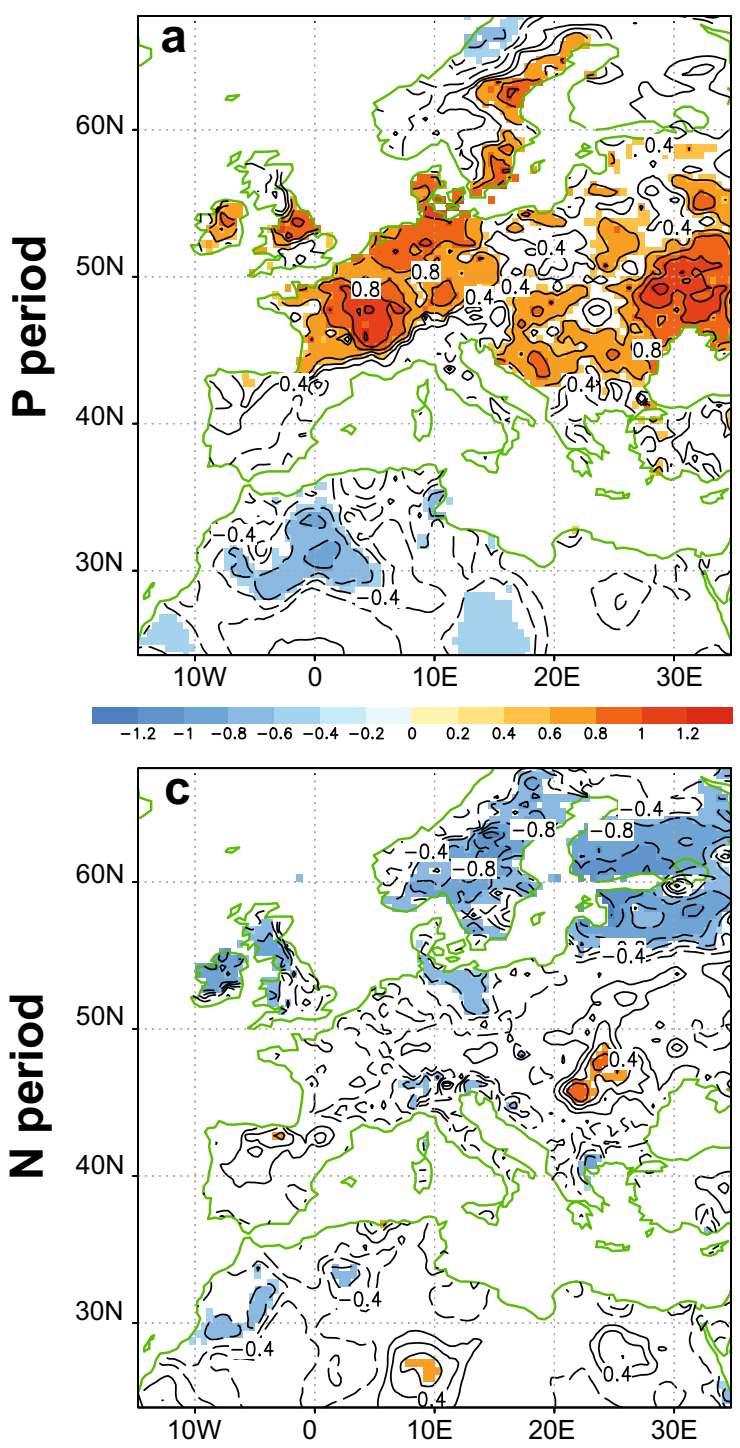

SLP
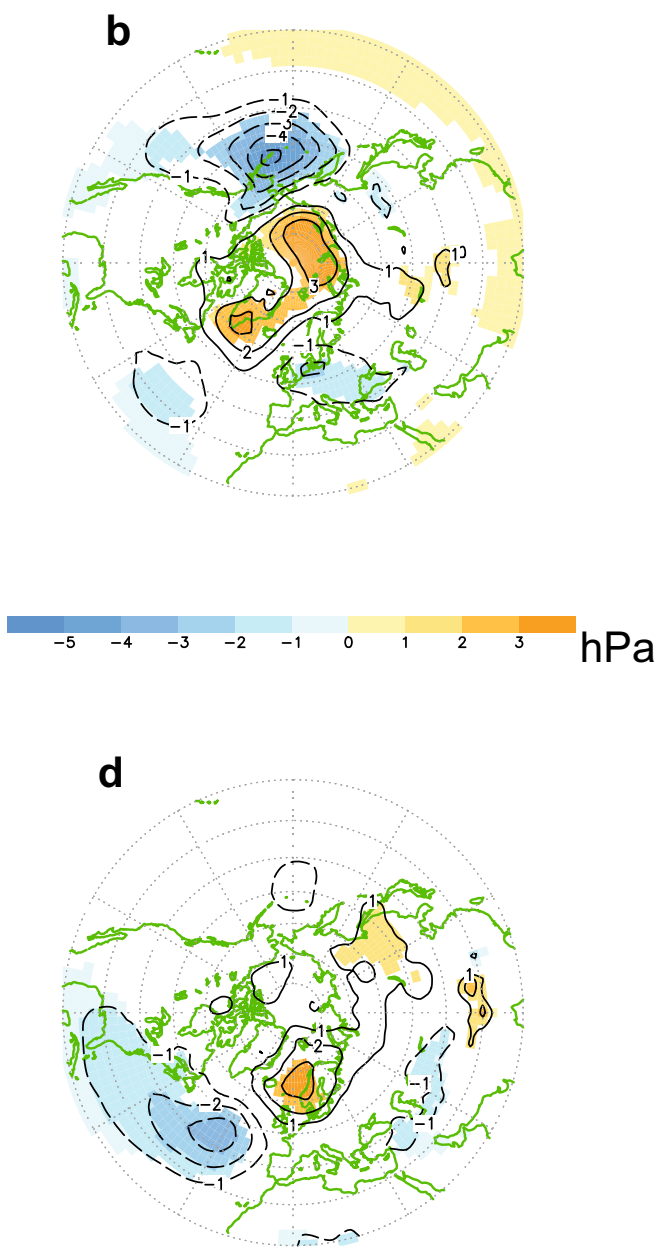

Fig. 1 Composite of anomalous fields in FMA for P period EN3.4 events: a standardized precipitation and b SLP (hPa). c, d Same as a, b but for N period EN3.4 events. Shading corresponds to statistically significant anomalies at the $90 \%$ confidence level (Monte-Carlo test)

opposite sign and mostly restricted to Scandinavia (Fig. 1c). The EN composite of SLP anomalies also displays different characteristics in $\mathrm{P}$ and $\mathrm{N}$ periods. During the $\mathrm{P}$ period, the FMA SLP pattern has a hemispheric distribution with a positive center of anomalies over the polar cap and negative anomalies over Aleutian Islands, western Atlantic and Europe (Fig. 1b). It partially resembles a pseudo-negative phase of NAO but with a strong wavy contribution. The negative SLP anomalies over the Atlantic and particularly, those over Europe are responsible for the higher precipitation than normal over central and Southern Europe of Fig. 1a. For the $\mathrm{N}$ period, the anomalies are mainly restricted to the EuroAtlantic area with a negative and a positive center over the
Atlantic and west of Scandinavia, respectively (Fig. 1d). The latter is related to the negative anomalies of precipitation over Northern Europe of Fig. 1c. In this case, the SLP anomaly is not significant over the pole.

Next, the SST patterns during the peak of EN events (December-January-February, DJF) have been analyzed to characterize the EN SST anomalies in the two different periods (Fig. 2). Stronger anomalous SSTs over the equatorial Pacific are found in the $\mathrm{P}$ than in the $\mathrm{N}$ period. The anomalies also present different location, being closer to the American coast in the $\mathrm{P}$ than in the $\mathrm{N}$ period. Thus, the SST pattern found in the $P$ period resembles an EP EN pattern, whereas it is similar to the $\mathrm{CP} E N$ in $\mathrm{N}$ period. This 


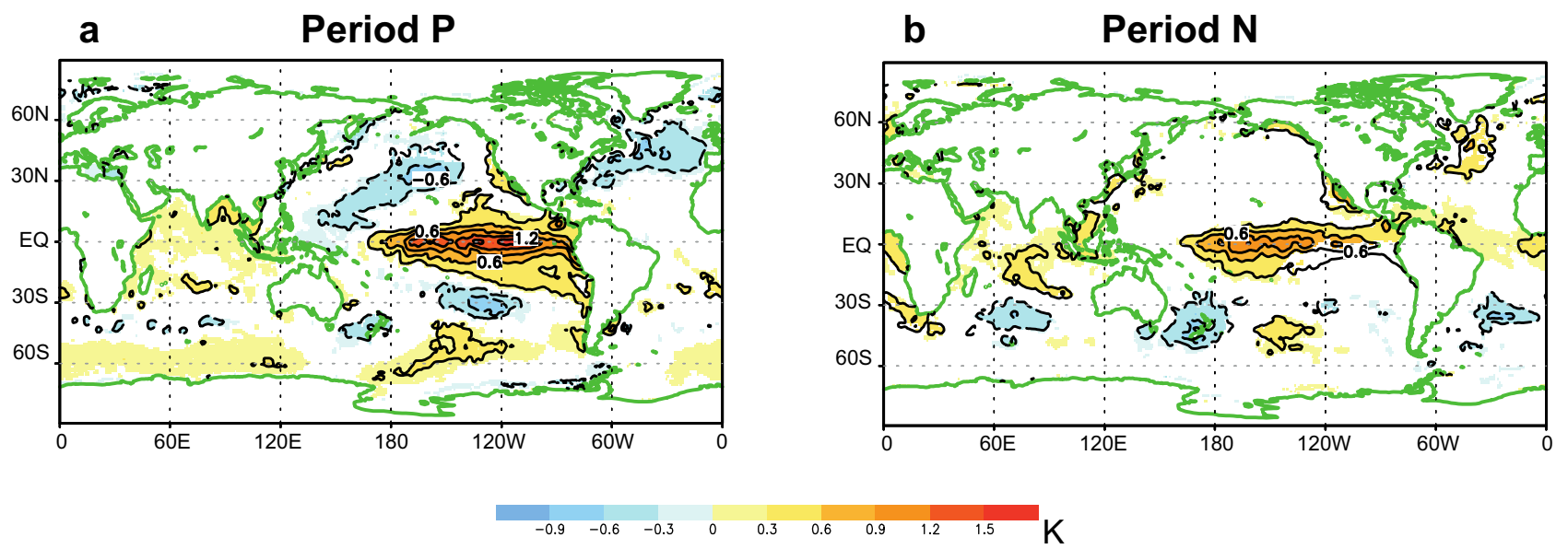

Fig. 2 Composite of anomalous SST in December-January-February (DJF) for EN winters in a P and b N periods. Shading indicates statistically significant anomalies at the $90 \%$ confidence level (Monte-Carlo test)

is confirmed by Table 1 that shows a high frequency of EP (CP) EN in $\mathrm{P}(\mathrm{N})$ period. The results agree with LópezParages et al. (2016a) that identified the strongest EN signal over Europe associated with EP EN during the P period and found differences in the associated tropospheric teleconnections. Nevertheless, as indicated in Sect. 1, EP and CP EN events have a distinct effect on the polar stratosphere and the stratospheric pathway of the EN teleconnection to Europe too, having the former a more relevant contribution (e.g.: Sung et al. 2014; Calvo et al. 2017). We have investigated if this is also the case for the EN effects in the two different periods of our study and if the contribution of this stratospheric pathway could then be added to the tropospheric results of López-Parages et al. (2016a) to explain the differences in the European precipitation response detected in Fig. 1.

Since stratospheric teleconnections start with a modulation of the tropospheric forcing, in particular, through the deepening of the Aleutian low and enhancement of upwardpropagating wave activity, we examine next changes in mid-tropospheric circulation. Figure $3 a$, b show the pattern of geopotential height (Z) at $500 \mathrm{hPa}$ (Z500) in November-December (ND). We have focused on early winter months based on two main reasons. First, we identify the strongest anomalous upward-propagating wave activity in November-December. Secondly, we are interested in the precursors of the anomalies that travel across the stratosphere and reach Europe from February, so we have to allow time to the atmosphere to complete the whole bridge. The
Fig. 3 Composite of anomalous geopotential height at $500 \mathrm{hPa}$ (m) in November - December (ND) for EN winters in a P and b $\mathrm{N}$ periods. Shading indicates statistically significant anomalies at the $90 \%$ confidence level (Monte-Carlo test)

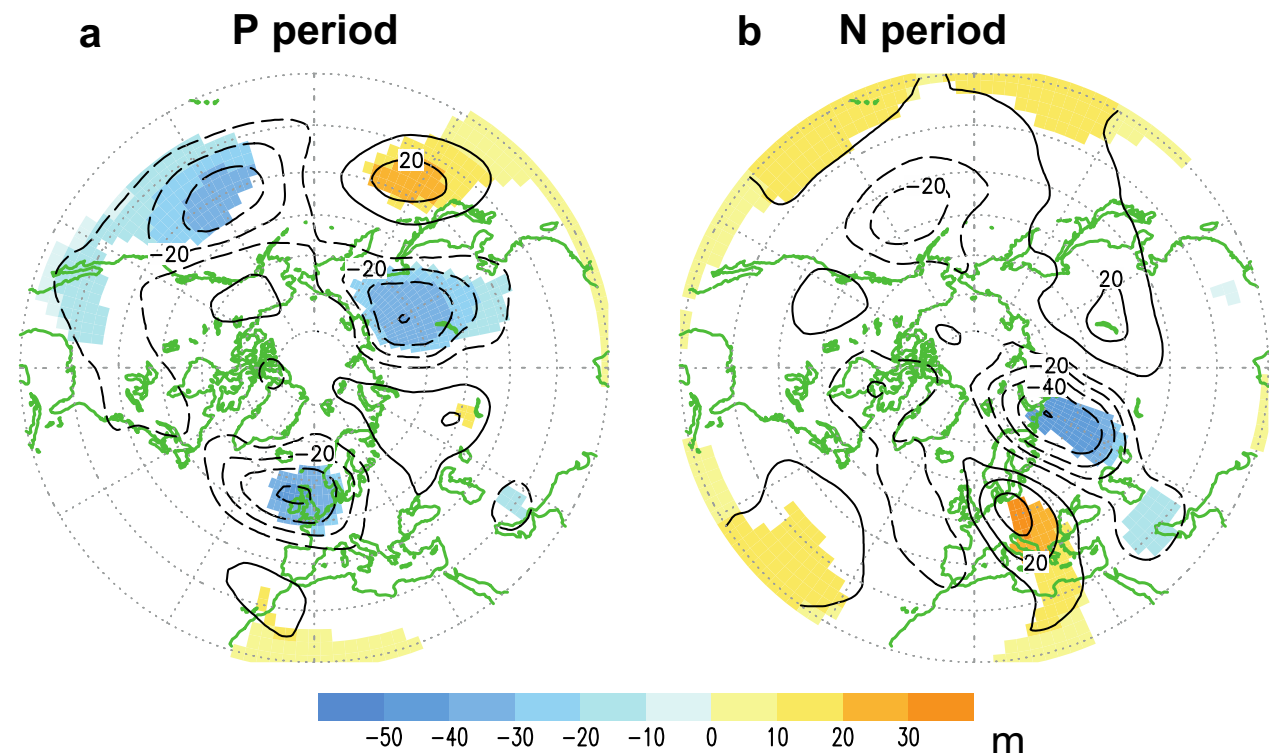


EN composite of the $\mathrm{P}$ period is associated with a significantly deeper Aleutian low in ND (Fig. 3a). In the N period, negative anomalies over the Aleutian Islands are also identified but they are weaker than in the P period and not significant (Fig. 3b). These patterns are in very good agreement with Rodríguez-Fonseca et al. (2016) and those obtained by Iza and Calvo (2015) for EP and CP El Nino events in reanalysis data. To verify the effects of mid-tropospheric changes on the injection of tropospheric wave activity into the stratosphere, the daily distribution of anomalous daily extratropical eddy heat flux at $100 \mathrm{hPa}$ is shown in Fig. 4a, averaged between $45^{\circ} \mathrm{N}$ and $75^{\circ} \mathrm{N}$ for November and December and composited during EN events for $\mathrm{P}$ and $\mathrm{N}$ periods. During EN events of the P period (red color in Fig. 4a), the upward propagating wave activity is stronger than normal, as denoted by a higher frequency of positive values of anomalous heat flux. In contrast, during EN events of the $\mathrm{N}$ period (gray color in Fig. 4a), the distribution of anomalous eddy heat flux is centered at small negative values, indicative of a negligible reduction in wave activity (Fig. 4a). Since previous studies have identified the wavenumber- 1 component (WN1) as the component undergoing the main EN-related enhancement of upward-propagating waves (e.g.: Garfinkel et al. 2008), we have examined the vertical propagation of the anomalous WN1 of geopotential height (Z) to verify if the change in the WN1 wave component is indeed representative of the variations of the total wave activity in the different periods (Fig. 4b). Anomalous waves for EN events during the $\mathrm{P}$ period are statistically significant in the stratosphere in both months and in phase with the climatological waves, leading to a constructive interaction of anomalous and climatological waves and thus, a strengthening of stationary WN1 wave (e.g.: Manzini et al. 2006; Ineson and Scaife 2009). In contrast, the eddy anomalies in the $\mathrm{N}$ period are weaker than in the P period and only statistically significant in the lowermost stratosphere in November. They are out of phase with the climatological ones in November and in quadrature in December (Fig. 4b). This indicates that the upward propagation of WN1 wave during EN events in the $\mathrm{N}$ period is reduced in November and it does not have much effect on the climatological wave activity in December, which would agree with the results for the total anomalous eddy heat flux.
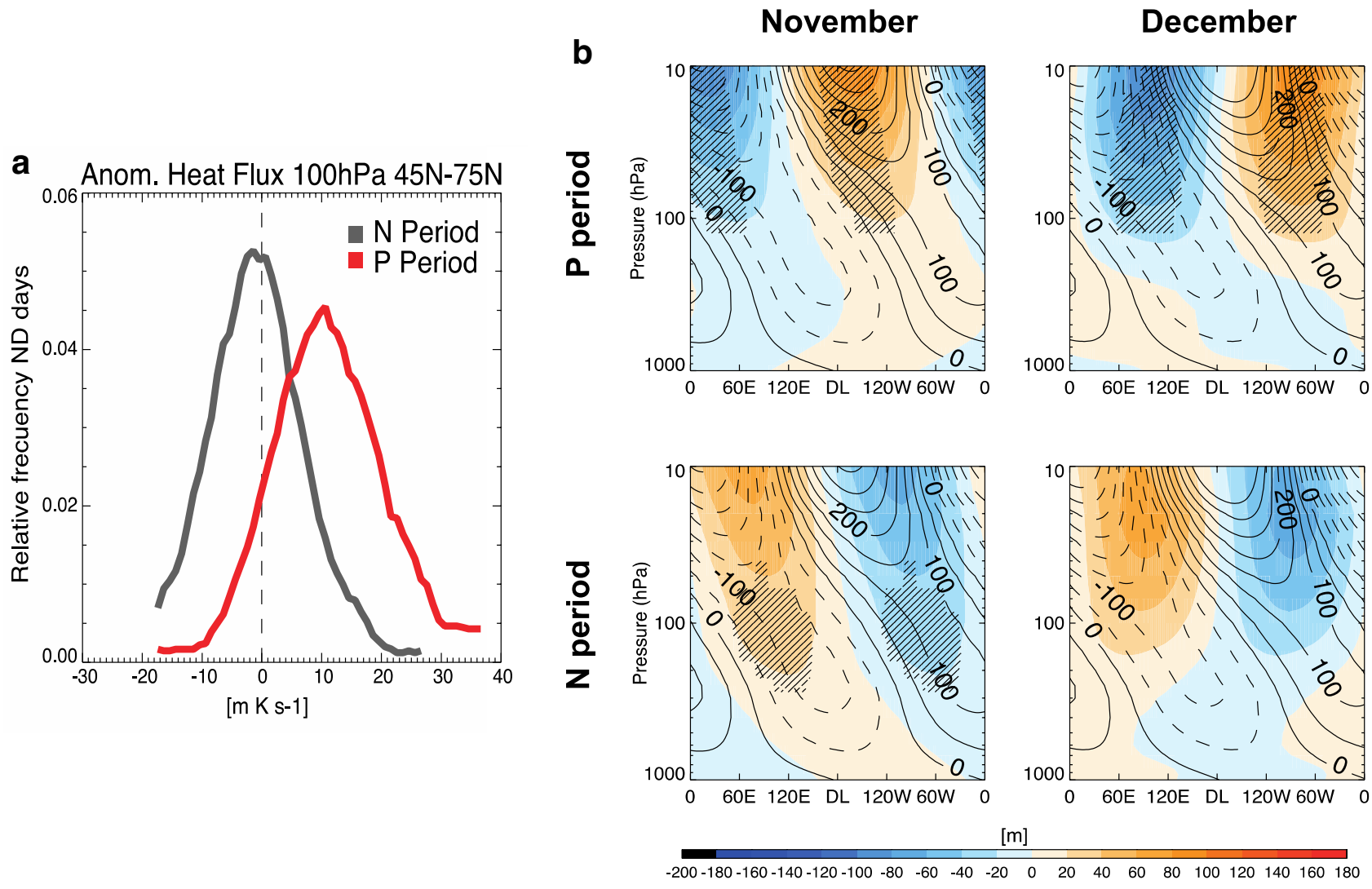

Fig. 4 a ND daily distribution of $100 \mathrm{hPa}$ eddy meridional heat flux anomalies $\left(\mathrm{K} \mathrm{m} \mathrm{s}^{-1}\right)$ averaged over $45^{\circ} \mathrm{N}-75^{\circ} \mathrm{N}, 10$-day filter applied for (gray) $\mathrm{N}$ and (red) $\mathrm{P}$ periods EN winters. b Composite of anomalies of WN1 component of $45^{\circ} \mathrm{N}-75^{\circ} \mathrm{N} \mathrm{Z} \mathrm{(m,} \mathrm{shading)} \mathrm{for} \mathrm{P} \mathrm{(top)} \mathrm{and}$
N (bottom) periods EN winters. Contours represent climatological waves. Stippling: statistically significant anomalies at the $90 \%$ confidence level with a Monte-Carlo test 


\section{a P period}

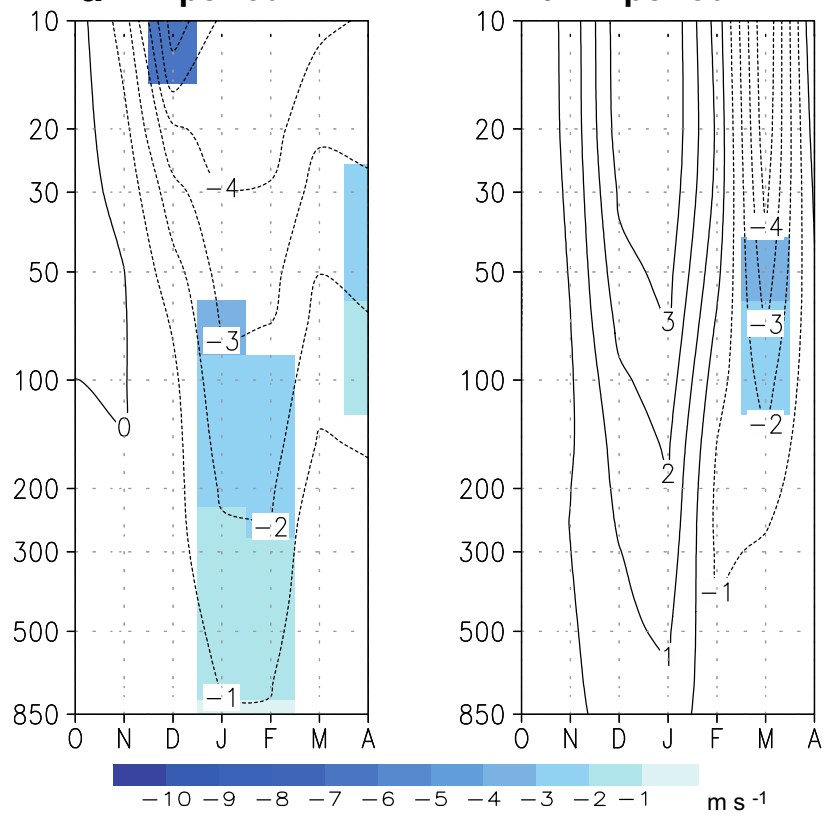

Fig. 5 Cross sections of anomalies of area-weighted $\mathrm{u}\left(\mathrm{m} \mathrm{s}^{-1}\right)$ averaged between $55^{\circ} \mathrm{N}$ and $70^{\circ} \mathrm{N}$ for El Niño events in a $\mathrm{P}$ period and b $\mathrm{N}$ period. Shading represents statistically significant anomalies at the $90 \%$ confidence level (Monte-Carlo test)

The stronger tropospheric forcing in early winter and the enhanced upward propagation into the stratosphere during EN events of the $\mathrm{P}$ period suggests that the polar stratosphere might be more affected by EN in the P period than the $\mathrm{N}$ period. This statement is confirmed in Fig. 5, where the temporal evolution of zonal mean zonal wind $(\bar{u})$ anomalies averaged between $55^{\circ} \mathrm{N}$ and $70^{\circ} \mathrm{N}$ is shown. In the stratosphere, these anomalies are representative of the state of the polar night jet and thus, the polar vortex. The P period is characterized by negative anomalies of $\bar{u}$ in the stratosphere, indicating a weakening of the polar vortex with a peak in December in the middle stratosphere when the anomalies are statistically significant (Fig. 5a). These anomalies descend, reaching the troposphere in January and persisting until February (although not always statistically significant, probably due to the small samples). Conversely, the $\mathrm{N}$ period polar night jet strengthens in early and mid-winter and weakens in later winter (Fig. 5b), but the anomalies are not statistically significant except for a small layer in the lower stratosphere in March. In addition, the anomalies do not descend with time as it happens in the $\mathrm{P}$ period. Thus, contrary to the $\mathrm{P}$ period, in the $\mathrm{N}$ period, the Euro-Atlantic precipitation anomalies of Fig. 1c are not connected to EN circulation anomalies in the stratosphere.

Thus, according to $\bar{u}$ results, the stratospheric influence on the troposphere only appears in January and February in the P period. However, up to now we analyzed the averaged European precipitation response in FMA in agreement with previous works (Fig. 1a). So, we next examine separately each FMA month in P period to test whether the FMA precipitation pattern in the P period (Fig. 1a) is mostly composed by the signal of any of those three months and then, decide if the stratospheric contribution (only present in February) is relevant. The comparison of the corresponding precipitation patterns (Fig. 6a, d, g) with that for FMA (Fig. 1a) reveals that the latter is a combination of robust signals in February and April. The contribution of February is however larger than that of April, probably because the EN influence over Europe involves both stratospheric and tropospheric pathways in February but it should occur through a tropospheric-only track in April. The SLP pattern in February shows a dipolar structure with positive anomalies over the polar cap and negative anomalies at mid-latitudes over the Atlantic (Fig. 6b). These negatives anomalies and specifically, their European part is the main responsible for the precipitation anomalies over Europe in Fig. 6a. The SLP dipolar pattern resembles partially a negative NAO phase in accordance with the stratospheric influence showed for February in Fig. 5a. Apart from the stratospheric mechanism, we cannot rule out the tropospheric pathway through the wavetrain from the Pacific that crosses the North America (the typical TNH pattern) in this month. The wavetrain can be identified in meridional wind at $250 \mathrm{hPa}$ patterns by the alternated anomalie s of opposite sign extending from the North Pacific to the North Atlantic (Fig. 6c).

In April, the SLP pattern differs from a dipolar structure as that shown in February and instead it presents a wavy pattern that extends from the Atlantic to Northern Europe (Fig. 6h). As it was found in February, the center of negative SLP anomalies over Northern Europe causes the precipitation anomalies over Europe seen in Fig. 6g. However, whereas the mentioned center in February results from the combination of the descent of stratospheric disturbances (Fig. 5a) and the arrival of an extratropical tropospheric wavetrain (Fig. 6c), the relative low over Europe in April is part of another tropospheric wavetrain with different origin. In this case, it originates in the Tropical North Atlantic region and propagates northward over the Atlantic, turning towards Europe as revealed by the pattern of meridional wind at $250 \mathrm{hPa}$ (contours in Fig. 6i). This wavetrain might be therefore related to the ENSO-induced warm SST anomalies over the Tropical North Atlantic (e.g.: Enfield and Mayer 1997) (shading in Fig. 6i). In fact, Ham et al. (2014) also showed a south-north SLP pattern related to these Tropical North Atlantic SST anomalies, similar to what we see in Fig. 6h. These authors highlighted the important role of these Atlantic SST anomalies to obtain the European atmospheric response to ENSO, as more recently studies such as 


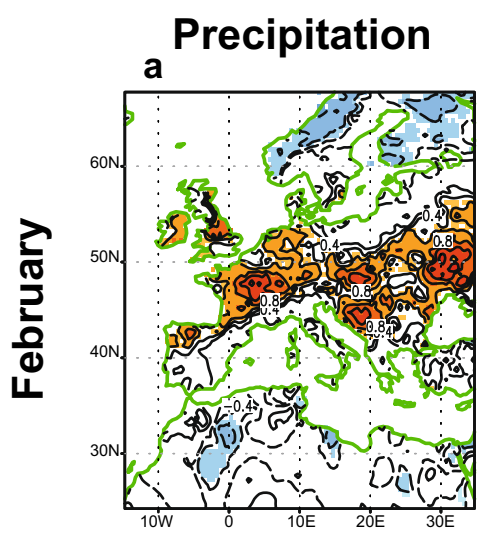

\section{SLP}

e
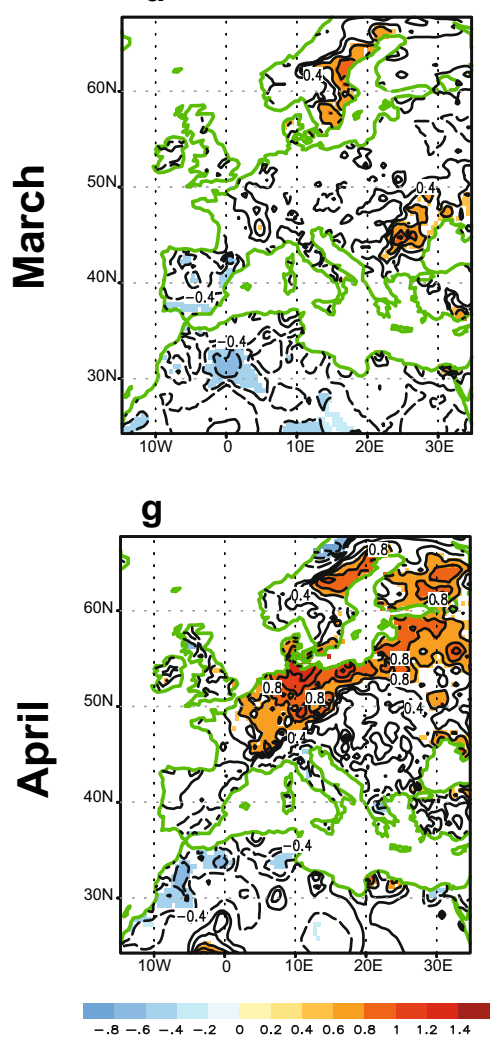
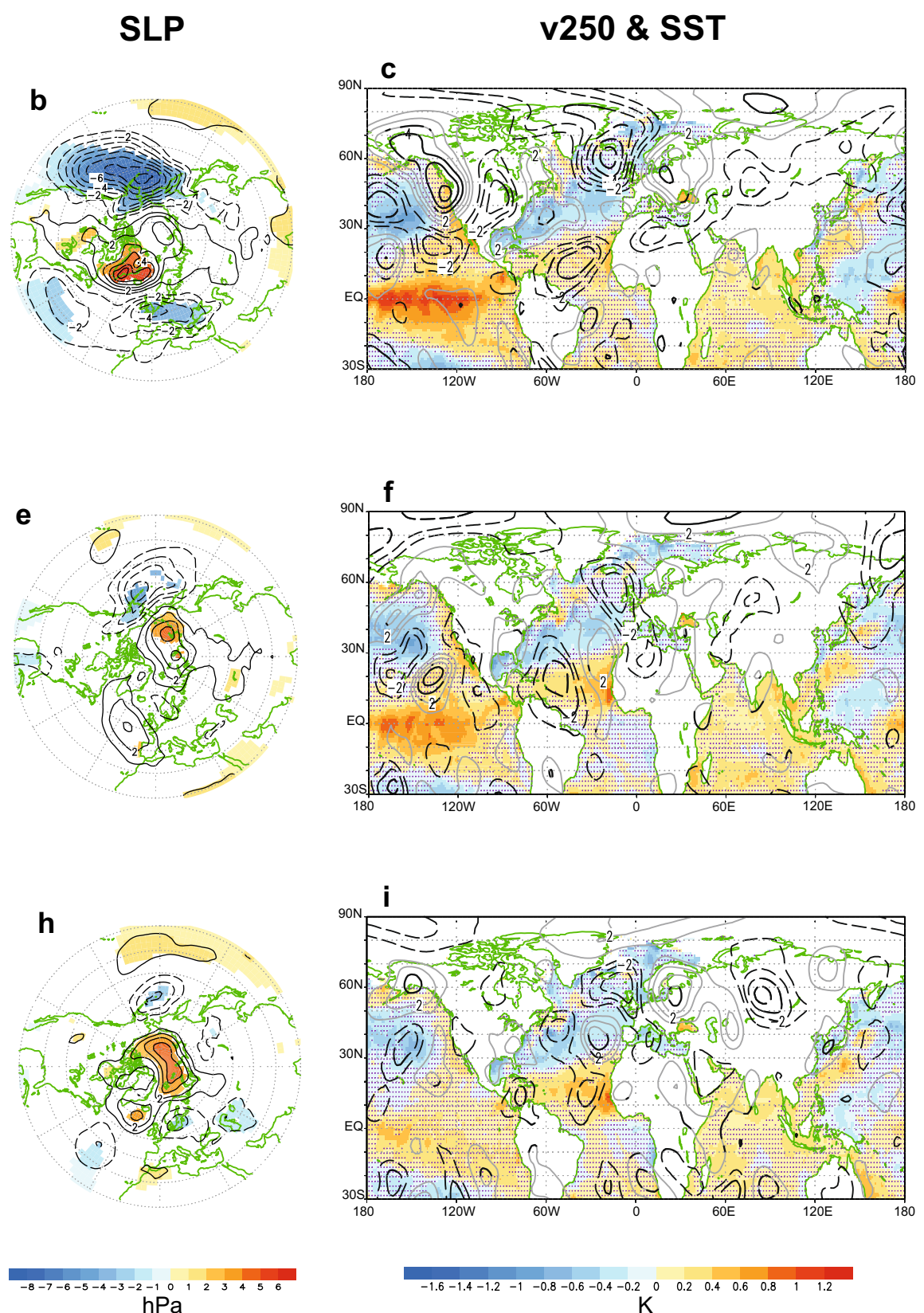

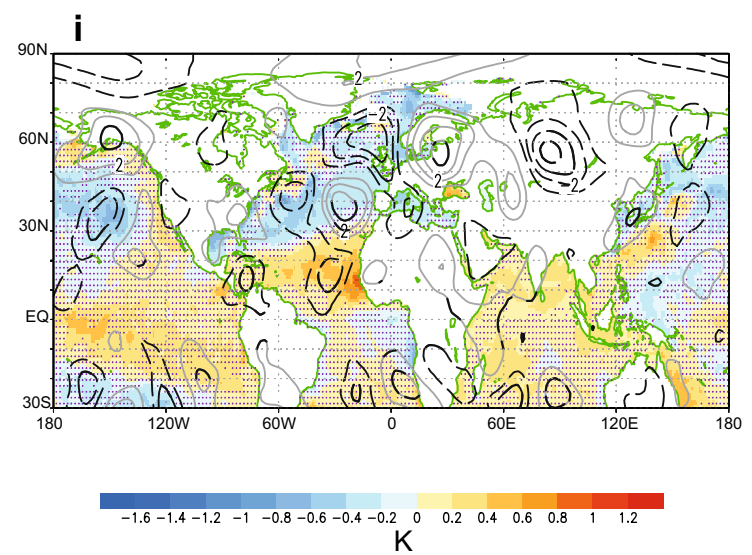

Fig. 6 Composite of anomalous a standardized precipitation, b SLP (hPa) and c SST (K, shading, purple dots indicate non-statistically significant values) and meridional wind $\left(\mathrm{m} \mathrm{s}^{-1}\right)$ at $250 \mathrm{hPa}$ (contours; gray (all values) and black (stat. significant, 90\% confidence level,

Knight et al. (2017), Scaife et al. (2017) and Herceg-Bulic et al. (2017) have also pointed out. In this regard, HercegBulic et al. (2017) have indicated the relevance of the North Atlantic to enable a delayed ENSO impact on Europe.

Finally, all the previous EN pathway are inactive or weak in March, explaining that we do not find relevant anomalies of SLP (precipitation) over the Atlantic (Europe) in this month. In particular, the stratospheric effect on the North
Monte-Carlo)) for P period EN events in February. $\mathbf{d}-\mathbf{f}$ and $\mathbf{g}-\mathbf{i}$ Same as $\mathbf{a}-\mathbf{c}$ but for March and April, respectively. Shading in $\mathbf{a}, \mathbf{b}, \mathbf{d}, \mathbf{e ,} \mathbf{g}$, h corresponds to statistically significant anomalies at the $90 \%$ confidence level (Monte-Carlo test)

Atlantic area is not anymore active (Fig. 5a), the TNH wave train has already weakened and the Tropical North Atlantic SSTs are weaker than in April (Fig. 6f). 


\section{Oceanic and atmospheric mean state in different periods}

Our results corroborate previous studies in that the location of the EN-related SST anomalies over the equatorial Pacific is a key element for establishing a stratospheric pathway and a strong European response to EN. Thus, we would like to explore further the conditions that lead to: (1) the predominance of a distinct type of EN (EP or CP) during a certain period of time, and (2) a modulation of the stratospheric pathway once it is triggered. All this is done by focusing on the background atmospheric and oceanic conditions.

Figure 7a shows in shading the difference in the annual climatology of SSTs between $\mathrm{P}$ and N periods. Warmer SSTs in the eastern equatorial Pacific appear in the P period compared to the $\mathrm{N}$ period, together with statistically significantly colder SSTs in the central North Pacific and a differential warming between the North and South Atlantic. The pattern of difference of SST over the North Pacific and Atlantic resembles a combination of a positive Pacific Decadal Oscillation (PDO) and a negative Atlantic Multidecadal Oscillation (AMO) signals respectively, being both oscillations characteristics of the internal multi-decadal ocean variability of the Pacific and Atlantic (Enfield et al. 2001; Mantua et al. 2002). The variability of SSTs for the mature phase of EN (DJF) also shows discrepancies between P and $\mathrm{N}$ periods (Fig. $7 \mathrm{~b}$ ). In particular, the difference in the SST standard deviation between these two periods reveals higher variability in the equatorial Eastern Pacific SST during the $\mathrm{P}$ period than the $\mathrm{N}$ period (Fig. 7b). The detected differences in the climatology and variability of SSTs of the equatorial Eastern Pacific between both periods agree with those found in the location and amplitude of EN SST anomalies
Fig. 7 P period -minus- $\mathrm{N}$ period differences of: a the annual climatology of SST (K, shading, purple dots indicate non-statistically significant values) and 500-hPa transient $\mathrm{v}^{\prime 2}\left(\mathrm{~m}^{2} \mathrm{~s}^{-2}\right.$, contours; gray (all values) and black (stat. significant, $90 \%$ confidence level, Monte-Carlo test)), b Standard deviation of SST in DJF (K, shading: stat. significance, F-Fisher test)

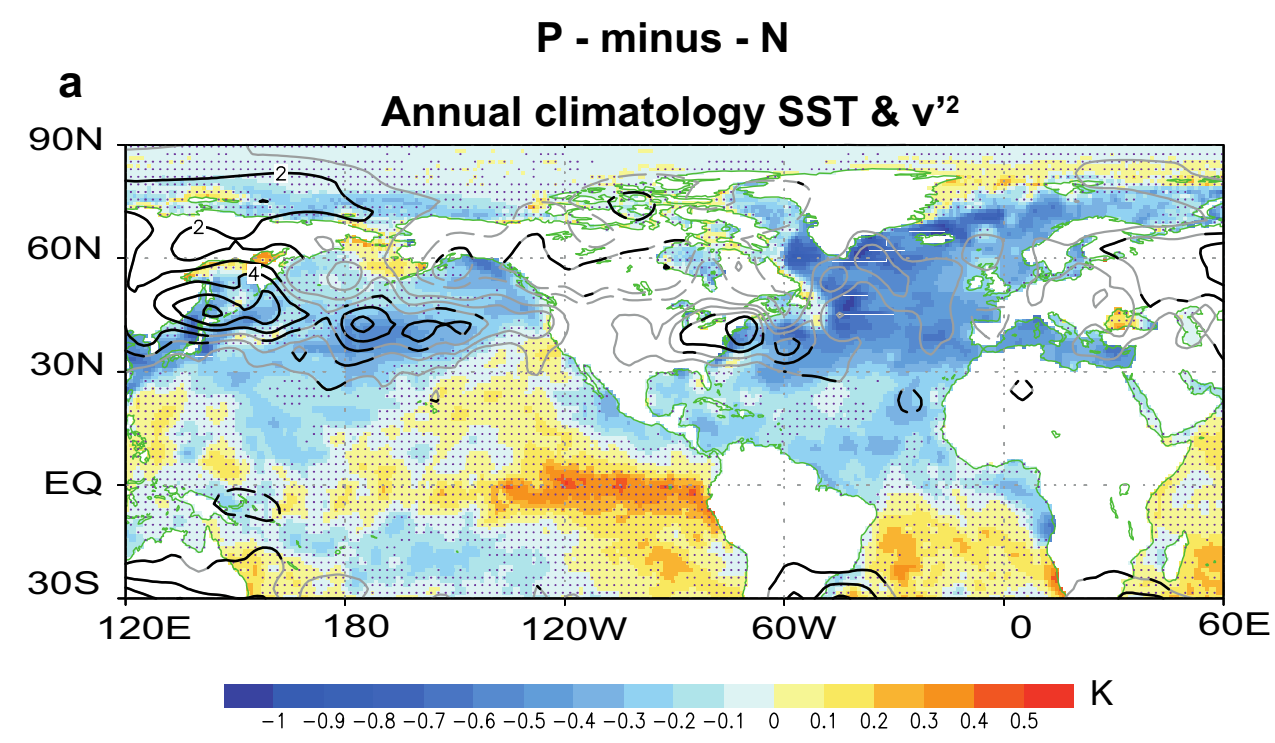

b

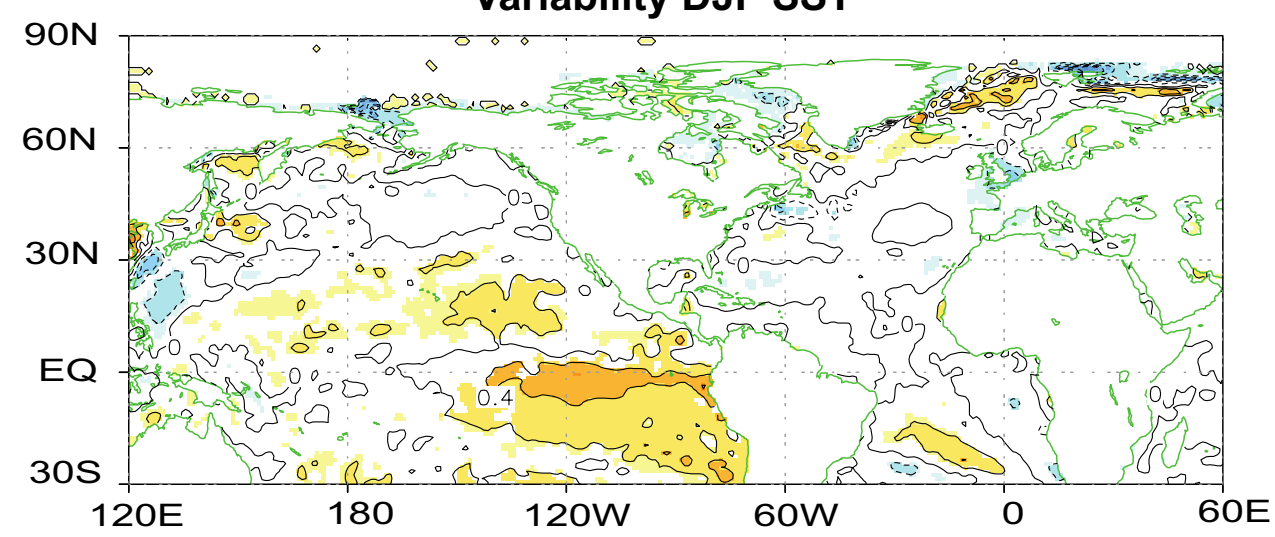


of Fig. 2. Those changes in the equatorial Pacific mean state are likely linked to the SST configuration in the Atlantic in agreement with previous studies (e.g.: Dong et al. 2006; Kucharski et al. 2016). For instance, Kucharski et al. (2016) documented a negative AMO phase to be responsible for higher variability and warmer SSTs in the equatorial Eastern Pacific through a change in the Walker circulation.

Concerning the extratropical Pacific SST, the observed SST configuration in Fig. 7a has also been linked to the AMO by changes in the general atmospheric circulation including a shift of the Intertropical Convergence Zone (ITCZ) (e.g.: Dong et al. 2006; Zhang and Delworth 2007; Chiang et al. 2002). In our case, the P-minus-N difference of the annual transient $\mathrm{v}^{\prime 2}$ at $500 \mathrm{hPa}$ shows positive values over the extratropical North Pacific (Fig. 7a, contours), indicative of stronger storm tracks in that basin in the $\mathrm{P}$ period than in $\mathrm{N}$ period. This would be connected to an intensification of the surface northward atmospheric eddy heat transport (Zhang and Delworth 2007) and an increase in the baroclinicity. The storm tracks changes impact on the main climatological circulation structures over Eastern Asian and North Pacific. For instance, in winter (DJF), the season focus of our study, the P-minus-N difference of Z500 shows negative values over the North Pacific and Siberia (Fig. 8a). This suggests an intensification and southward shift of the Aleutian low in $\mathrm{P}$ period respect to $\mathrm{N}$ period and a westward shift of the Siberian High. The mentioned North Pacific atmospheric differences add to the direct influence of the Atlantic
SSTs over the equatorial Pacific to determine the EN events characteristics. More specifically, a deep Aleutian low has been documented to precede the occurrence of EP EN (Yu and Kim 2011), but especially when accompanied by a weakening of the North Pacific Hadley cell (Yu et al. 2012), which are exactly the conditions of the $\mathrm{P}$ period respect to the $\mathrm{N}$ period. Indeed, by computing the Hadley cell strength as the vertical shear of $\mathrm{v}$ between 200 and $850 \mathrm{hPa}$ averaged over $120^{\circ} \mathrm{E}-280^{\circ} \mathrm{E}$ along $10^{\circ} \mathrm{N}$ (Oort and Yienger 1996), we found that the cell strength is $0.53 \mathrm{~m} \mathrm{~s}^{-1}$ for $\mathrm{P}$ period and $0.83 \mathrm{~m} \mathrm{~s}^{-1}$ for $\mathrm{N}$ period in DJF. Thus, the North Pacific Hadley cell is weaker in the $\mathrm{P}$ period than in $\mathrm{N}$ period although not statistically significant at a $90 \%$ confidence level. Overall, we can conclude that the global SLP and SST patterns are consistent with the preferred occurrence of EP El Niño events in the $\mathrm{P}$ period.

Next, since we are particularly interested in the modulation of the stratospheric pathway, we examine the differences in the mean state at stratospheric and tropospheric levels between $\mathrm{P}$ and $\mathrm{N}$ periods. The intensification of the climatological Aleutian low in $\mathrm{P}$ respect to $\mathrm{N}$ depicted in Fig. 8a together with the negative center of geopotential height differences over Eastern Asia imply changes in climatological tropospheric forcing. In fact, they affect the upward-propagating stationary waves (particularly WN1 wave) as both centers are located over the negative antinode of the climatological WN1 wave of $\mathrm{Z}$ in the middle troposphere (e.g.: Garfinkel et al. 2010). Indeed, it leads

\section{P - minus - N}
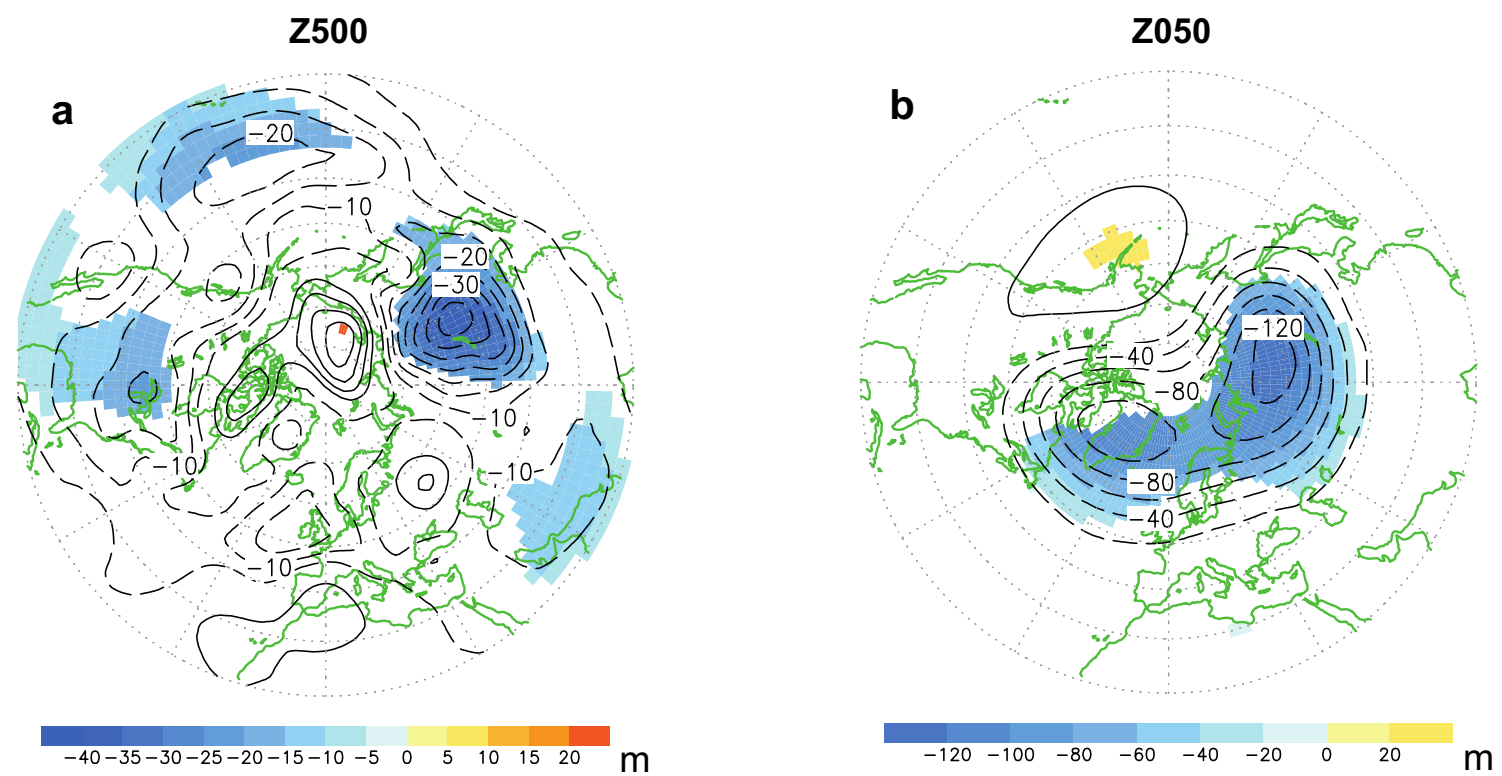

Fig. 8 P period -minus- N period differences in DJF of a Z (m) at $500 \mathrm{hPa}$ (shading: stat. significance, Monte-Carlo test) and b Z (m) at $50 \mathrm{hPa}$ (shading: stat. significance, Monte-Carlo test) 
to a statistically significantly stronger climatological WN1 component of extratropical $\mathrm{Z}$ at $50 \mathrm{hPa}(\mathrm{Z} 050)$ in $\mathrm{P}$ period than in $\mathrm{N}$ period (172.5 vs $125.1 \mathrm{~m}$ ). Consequently, the mean state of the polar vortex also undergoes differences between both periods and the pattern of difference of Z050 shows a displaced vortex towards Eurasia and a deeper Aleutian high in $\mathrm{P}$ period respect to $\mathrm{N}$ period (Fig. $8 \mathrm{~b}$ ). These differences in the stratospheric background state would also modulate the impact of the wave forcing associated with the EN on the polar vortex. For instance, during the P period, the EN mid-tropospheric circulation pattern of Fig. 3a resembles the pattern of difference in the climatology of Z500 of Fig. 8a, suggesting that the anomalous WN1 associated with EN, and its related impacts, would be intensified under that mean state. Additionally, this EN-related anomalous WN1 wave activity will be more effective to disturb the vortex as the latter is already displaced towards Eurasia.

\section{Summary and discussion}

Motivated by previous results that found interdecadal variability in EN signal in precipitation over Europe (e.g.: Mariotti et al. 2002, LP2015) and by the existence of a stratospheric pathway of EN teleconnection in this region, we have analyzed the role of the stratosphere in the EN teleconnections in periods with a different EN signal in European precipitation in reanalysis data. The tropospheric mechanisms in these different periods have been already addressed in other studies (LP2015; López-Parages et al. 2016a and b), but the stratospheric part of this linkage remained to be investigated in detail. In addition, we have focused not only on the possible pathways of the EN teleconnection to Europe but we have also examined the oceanic and atmospheric mean states that favor or hinder these pathways. Thus, we present here a comprehensive study where tropospheric and stratospheric knowledge at different time scales are investigated.

The key conclusions of our study are the following:

- Only periods with strong European precipitation response to EN show an active role of the polar stratosphere in this teleconnection in agreement with Rodríguez-Fonseca et al. (2016). The location of EN SST anomalies is different in periods with strong and weak EN impact on Europe, such that periods with strong and weak EN impact on Europe are mostly related to Eastern and Central EN SST anomalies, respectively. This different SST pattern ultimately modulates the impact on the tropospheric Aleutian low and consequently, on the upwardpropagating stationary $\mathrm{WN} 1$ wave.

- The EN signal on European precipitation in late winter that travels through the stratospheric pathway is only one part of the total signal and it is concentrated in February. Some signal also reaches Europe through two tropospheric tracks, the TNH wavetrain in February and another wavetrain in April originated over the tropical North Atlantic due to EN-induced SST anomalies. Considering this result, two important remarks should be made. First, both EN tropospheric and stratospheric teleconnections are relevant and required to obtain a strong EN response in precipitation in Europe. This would agree with LP2015 who found these alternated periods in the signal of EN in Europe in a low-top model, i.e., without a well-resolved stratosphere. This is also consistent with Herceg-Bulic et al. (2017) that showed that the persistence of wintertime ENSO signal in both the stratosphere and the North Atlantic is required to enable the delayed ENSO impact on Europe in spring, and Scaife et al. (2017) and Knight et al. (2017) that highlighted the importance of including tropical Atlantic influence on seasonal forecast to obtain a correct signal of ENSO on Europe. Secondly, analysis of seasonal averages for late winter must be taken with caution because it is a transition season in which different mechanisms might work in different months and the predominant one might mask the rest.

- Different climatological SST structures over the Atlantic and North Pacific and their associated atmospheric conditions explain the preferred location of EN SST anomalies in different periods. In particular, a negative AMO phase over the Atlantic and a positive PDO over the North Pacific have been found to favor the occurrence of EP EN SST during the P period, in agreement with a change in the general atmospheric circulation. The climatological oceanic configuration affects the atmospheric background, resulting in a deeper Aleutian low and a westward shift of the Siberian high in the troposphere, and a displaced stratospheric polar vortex towards Eurasia in agreement with Li et al. (2018). Under these background conditions an anomalous WN1 wave activity would be more effective for disturbing the polar vortex and thus, initiating the stratospheric EN pathway.

Therefore, our results suggest that a strong European response to $\mathrm{EN}$ is due to both active tropospheric and stratospheric pathways that connect the tropical ENSO signal with late winter European weather. As for the stratospheric pathway, some authors have suggested that the occurrence of MSWs is extremely important for obtaining this EN strong signal over Europe (e.g.: Ineson and Scaife 2009; Cagnazzo and Manzini 2009; Butler et al. 2014; Domeisen et al. 2015). However, the frequency of MSWs is indeed high for both $\mathrm{P}$ and $\mathrm{N}$ periods. In particular, 6 out of $8 \mathrm{EN}$ winters in the P period have a MSW and 4 out of 6 in the $\mathrm{N}$ period (Table 1). Although contradictory 
at a first sight, the discrepancies between our results and previous studies might be explained. For instance, the mentioned studies focused on canonical EN events that have associated a warming of the polar stratosphere and in that case, the occurrence of MSWs was needed for the downward propagation of the signal. In contrast, EN events in the $\mathrm{N}$ period are predominantly $\mathrm{CP}$ (Table 1), the EN type that does not show a robust warming on the stratosphere (Iza and Calvo 2015). Thus, although MSWs occur during $\mathrm{EN}$ winters of the $\mathrm{N}$ period, there might not be an EN signal in the stratosphere to propagate downward. However, the limited number of events avoid us to derive robust conclusions on this issue. Apart from MSW, other stratospheric phenomenon such as the QuasiBiennial Oscillation (QBO) has also been identified as a modulating factor of the EN signal in Europe, being stronger under a westerly phase of the QBO (Brönnimann 2007). Nevertheless, we have not found this relationship (not shown). It seems, though, that the location of the EN SST anomalies over the equatorial Pacific is a key element for establishing the EN stratospheric pathway. This would agree with previous studies (e.g.: Iza and Calvo 2015; Calvo et al. 2017). However, it is worthy highlighting that our work is not simply repeating the different $\mathrm{CP}$ versus EP results as documented in those previous studies. The focus of our study is the analysis of the non-stationarity of the EN teleconnections to Europe through the stratosphere regardless of the type of EN, and the contribution of these teleconnections to the total signal, when they are active. Thus, although there is a preference for one $\mathrm{EN}$ flavor in $\mathrm{P}$ and $\mathrm{N}$ periods, there are EN events of all types in both but under different oceanic mean state. Additionally, these former studies made a special emphasis on the disparity of the stratospheric response to each type of EN depending on the occurrence of SSWs that we are not able to do because of the limitations explained before. Our results point out though that the oceanic mean state in different periods and its associated atmospheric background is extremely relevant first to determine the predominant location of the EN SST in each period and secondly, to establish the different EN teleconnections in the troposphere as shown by LP2015 and López-Parages et al. (2016a) and consequently, in the stratosphere. To schematize the results on the oceanic and atmospheric mean state and their link to the EN signal in Europe, the time evolution of standardized indices that characterize the mean state of different components is presented in Fig. 9. The indices considered are the EN3 as a representative of EP EN events (orange line), AMO (the yellow line), PDO (the green line) and a time series of the P-minus-N Z050 pattern constructed by projecting the pattern of Fig. $8 \mathrm{~b}$ on the Z050 field in DJF

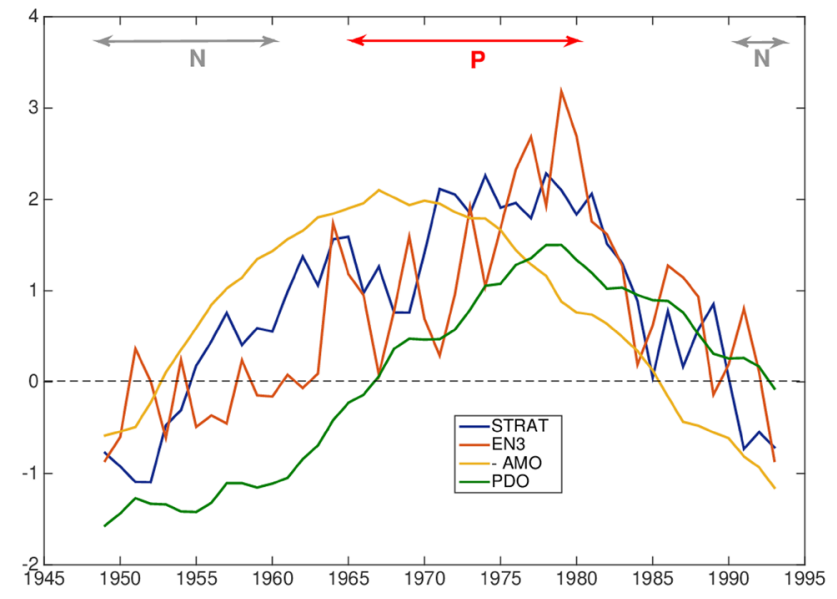

Fig. 9 20-year running mean of different standardized indices: the stratospheric index based on the evolution of P-minus-N difference pattern of Z050 (blue line), El Niño3 index (orange line), AMO (with reversed sign, yellow line) and PDO (green line). The years in the $\mathrm{x}$-axis correspond to forwarded 20 -years period (i.e. 1960 stands for 1960-1979). The arrows at the top indicate then only approximately the $\mathrm{N}$ and $\mathrm{P}$ periods and are included just to help in the interpretation of the results

from 1948 to 2012 (blue line). The high agreement in the evolution of EN3 and PDO was expected as reported by different studies (e.g.: Newman et al. 2016). Interestingly, the evolution of these two indices resembles very much the one of the WN1 pattern in the stratosphere, confirming Hurwitz et al. (2012)'s results that related a disturbed polar vortex to cool SSTs over the central North Pacific through the deepening of the Aleutian low and the subsequent intensification of the stationary WN1 wave. The AMO index undergoes a similar evolution as the other indices but with a lag of around -10 years in agreement with Zhang and Delworth (2007). In addition, although the 20-year running mean applied to these indices does not allow a straightforward comparison between the $\mathrm{P}$ and $\mathrm{N}$ periods and the evolution of the indices, the $\mathrm{P}$ period window corresponds with periods where all these indices show high positive values (negative in the case of AMO) and the opposite for the $\mathrm{N}$ period.

Finally, we note that our ability to draw robust conclusions is hampered by the short observational period, particularly in the stratosphere. The analysis of climate model simulations would reduce part of this uncertainty and would enable us to address some open questions such as those related to the role of MSWs or QBO in the different periods. It would be interesting to analyze either the next CMIP6 simulations or sensitivity experiments to verify the conclusions presented here. However, that analysis is out of the scope of the present paper. 
Acknowledgements BA was supported by the Natural Environment Research Council grant NE/M006123/1, the European Project 603557-STRATOCLIM and "Ayudas para la contratación de personal postdoctoral en formación en docencia e investigación en departamentos de la UCM". JLP and BRF were funded by the European Project PREFACE. MI and NC acknowledge support from the European Project 603557-STRATOCLIM under program FP7-ENV.2013.6.1-2. NC was also supported in part by the Spanish Ministry of Economy and Competitiveness through the PALEOSTRAT (CGL2015-69699-R) project. NCEP reanalysis and University of Delaware precipitation data were provided by the NOAA/OAR/ESRL PSD, Boulder, Colorado, USA from their Website at https://www.esrl.noaa.gov/psd. Hadley Centre Sea Ice and Sea Surface Temperature data are available at: http:// www.metoffice.gov.uk/hadobs/hadisst/data/download.html. The AMO and PDO indices were obtained from the website: https://www.esrl. noaa.gov/psd/data/climateindices/list/. The authors thank the anonymous reviewers for their helpful comments.

Open Access This article is distributed under the terms of the Creative Commons Attribution 4.0 International License (http://creativeco mmons.org/licenses/by/4.0/), which permits unrestricted use, distribution, and reproduction in any medium, provided you give appropriate credit to the original author(s) and the source, provide a link to the Creative Commons license, and indicate if changes were made.

\section{References}

Bell CJ, Gray LJ, Charlton-Perez AJ, Joshi MM, Scaife AA (2009) Stratospheric Communication of El Niño Teleconnections to European Winter. J Clim 22:4083-4096

Brönnimann S (2007) Impact of El Niño-Southern Oscillation on European climate. Rev Geophys 45:RG3003. https://doi. org/10.1029/2006RG000199

Butler AH, Polvani LM, Deser C (2014) Separating the stratospheric and tropospheric pathways of El Niño-Southern Oscillation teleconnections. Environ Res Lett 9:024014. https://doi. org/10.1088/1748-9326/9/2/024014

Butler AH, Seidel DJ, Hardiman SC, Butchart N, Birner T, Match A (2015) Defining sudden stratospheric warmings. Bull Am Meteor Soc 96:1913-1928

Cagnazzo C, Manzini E (2009) Impact of the stratosphere on the winter tropospheric teleconnections between ENSO and the North Atlantic and European region. J Clim 22:1223-1238

Calvo N, Iza M, Hurwitz M, Manzini E, Peña-Ortiz C, Butler A, Cagnazzo C, Ineson S, Garfinkel C (2017) Northern Hemisphere stratospheric pathway of different El Niño flavors in stratosphereresolving CMIP5 models. J Clim 30:4351-4371

Chiang JC, Kushnir Y, Giannini A (2002) Deconstructing Atlantic Intertropical Convergence Zone variability: Influence of the local cross-equatorial sea surface temperature gradient and remote forcing from the eastern equatorial Pacific. J Geophys Res 107(D1). https://doi.org/10.1029/2000JD000307

Domeisen DIV, Butler AH, Fröhlich K, Bittner M, Müller WA, Baehr J (2015) Seasonal predictability over Europe arising from El Niño and stratospheric variability in the MPI-ESM seasonal prediction system. J Clim 28:256-271

Dong B, Sutton RT, Scaife AA (2006) Multidecadal modulation of El Niño-Southern Oscillation (ENSO) variance by Atlantic Ocean sea surface temperatures. Geophys Res Lett 33:L08705. https:// doi.org/10.1029/2006GL025766
Enfield DB, Mayer DA (1997) Tropical Atlantic sea surface temperature variability and its relation to El Niño-Southern Oscillation. J Geophys Res 102:929-945

Enfield DB, Mestas-Nuñez AM, Trimble PJ (2001) The Atlantic multidecadal oscillation and its relation to rainfall and river flows in the continental US. Geophys Res Lett 28:2077-2080

García-Herrera R, Calvo N, García RR, Giorgetta MA (2006) Propagation of ENSO temperature signals into the middle atmosphere: A comparison of two general circulation models and ERA-40 reanalysis data. J Geophys Res 111:D06101. https://doi. org/10.1029/2005JD006061

García-Serrano J, Cassou C, Douville H, Giannini A, Doblas-Reyes FJ (2017) Revisiting the ENSO teleconnection to the Tropical North Atlantic. J Clim 30:6945-6957

Garfinkel CI, Hartmann DL (2008) Different ENSO teleconnections and their effects on the stratospheric polar vortex. J Geophys Res 113:D18114. https://doi.org/10.1029/2008JD009920

Garfinkel CI, Hartmann DL, Sassi F (2010) Tropospheric precursors of anomalous Northern Hemisphere stratospheric polar vortices. J Clim 23:3282-3299

Ham Y-G, Sung M-K, An S-I, Schubert SD, Kug J-S (2014) Role of Tropical Atlantic SST variability as a modulator of El Niño teleconnections. Asia-Pacific J Atmos Sci 50:1-15

Herceg-Bulic I, Mezzina B, Kucharski F, Ruggieri P, King MP (2017) Wintertime ENSO influence on late spring European climate: the stratospheric response and the role of North Atlantic SST. Int J Climatol 37:87-108

Hurwitz MM, Newman PA, Garfinkel CI (2012) On the influence of North Pacific sea surface temperature on the Arctic winter climate. J Geophys Res 117:D19110. https://doi.org/10.1029/2012J D017819

Ineson S, Scaife AA (2009) The role of the stratosphere in the European climate response to El Niño. Nat Geosci 2:32-36

Iza M, Calvo N (2015) Role of Stratospheric Sudden Warmings on the response to Central Pacific El Niño., Geophys Res Lett. https:// doi.org/10.1002/2014GL062935

Kalnay ME et al. (1996) The NCEP/NCAR 40-year reanalysis project. Bull Am Meteorol Soc 77:437-471. https://doi. org/10.1175/1520-0477(1996)077<0437:TNYRP>2.0.CO;2.

Knight JR, Maidens A, Watson PAG, Andrews M, Belcher S, Brunet G, Fereday D, Folland CK, Scaife AA, Slingo J (2017) Global meteorological influences on the record UK rainfall of winter 2013-14, Environ. Res Lett 12:074001

Kucharski F, Ikram F, Molteni F, Farnetti R, Kang I-S, No H-H, King MP, Giuliano G, Mogensen K (2016) Atlantic forcing of Pacific decadal variability. Clim Dyn 46:2337-2351

Li F, Orsolini YJ, Wang H, Gao Y, He S (2018) Modulation of the Aleutian-Icelandic low seesaw and its Surface impacts by the Atlantic Multidecadal Oscillation. Adv Atmos Sci 35:95-105

López-Parages J, Rodríguez-Fonseca B (2012) Multidecadal modulation of El Niño influence on the Euro-Mediterranean rainfall. Geophys Res Lett 39:L02704. https://doi.org/10.1029/2011GL050049

López-Parages J, Rodríguez-Fonseca B, Terray L (2015) A mechanism for the multidecadal modulation of ENSO teleconnection with Europe. Clim Dyn 45:867-880

López-Parages J, Rodríguez-Fonseca B, Dommenget D, Frauen C (2016a) ENSO influence on the North Atlantic European climate: a non-linear and non-stationary approach. Clim Dyn 47:2071-2084

López-Parages J, Rodríguez-Fonseca B, Mohino E, Losada T (2016b) Multidecadal Modulation of ENSO Teleconnection with Europe in Late Winter: Analysis of CMIP5 Models. J Clim 29:8067-8081

Mantua NJ, Hare SR (2002) The Pacific decadal oscillation. J Oceanography 58:35-44

Manzini E, Giorgetta MA, Esch M, Kornblueh L, Roeckner E (2006) The influence of sea surface temperatures on the Northern winter 
stratosphere: ensemble simulations with the MAECHAM5 Model. J Clim 19:3863-3882

Mariotti A, Zeng N, Lau K-M (2002) Euro-Mediterranean rainfall and ENSO - a seasonally varying relationship. Geophys Res Lett 29:1621. https://doi.org/10.1029/2001GL014248

Mitchell DM, Gray LJ, Charlton-Perez AJ (2011) The structure and evolution of the stratospheric vortex in response to natural forcings. J Geophys Res 116:D15110. https://doi.org/10.1029/2011J D015788

Moron M, Gouirand I (2003) Seasonal modulation of the ENSO relationship with sea level pressure anomalies over the North Atlantic in October-March 1873-1996. Int J Climatol 23:143-155

Newman M, Alexander MA, Ault TR, Cobb KM, Deser C, Di Lorenzo E, Mantua NJ, Miller AJ, Minobe S, Nakamura H, Schneider N, Vimont DJ, Phillips AS, Scott JD, Smith CA (2016) The Pacific Decadal oscillation, revisited. J Clim 29:4399-4427

Omrani N-E, Bader J, Keenlyside NS, Manzini E (2016) Troposphere-stratosphere response to large-scale North Atlantic Ocean variability in an atmosphere/ocean coupled model. Clim Dyn 46:1397-1415

Oort AH, Yienger JJ (1996) Observed interannual variability in the Hadley circulation and its connection to ENSO. J Clim 9:2751-2767

Peixoto JP, Oort AH (1992) Physics of climate, Springer, Berlin p 520

Rayner NA, Parker DE, Horton EB, Folland CK, Alexander LV, Rowell DP, Kent EC, Kaplan A (2003) Global analyses of sea surface temperature, sea ice, and night marine air temperature since the late nineteenth century. J Geophys Res 108(D14):4407. https:// doi.org/10.1029/2002JD002670

Reichler T, Kim J, Manzini E, Kröger J (2012) A stratospheric connection to Atlantic climate variability. Nat Geos 5:783-787

Rodríguez-Fonseca B, Suárez-Moreno R, Ayarzagüena B, LópezParages J, Gómara I, Villamayor J, Mohino E, Losada T, Castaño A (2016) A review of ENSO influence on the North Atlantic. A non stationary signal. Atmosphere 7:87. https://doi.org/10.3390/ atmos7070087
Scaife AA, Comer RE, Dunstone NJ, Knight JR, Smith DM, MacLachlan C, Martin N, Peterson KA, Rowlands D, Carroll EB, Belcher S, Slingo J (2017) Tropical rainfall, Rossby waves and regional winter climate predictions. Q J Meteorol Soc 143:1-11

Schimanke S, Köper J, Spangehl T, Cubasch U (2011) Multi-decadal variability of sudden stratospheric warmings in an AOGCM. Geophys Res Lett 38:L01801. https://doi.org/10.1029/2010GL045756

Sung M-K, Kim B-M, An S-I (2014) Altered atmospheric responses to eastern Pacific and central Pacific El Niños over the North Atlantic region due to stratospheric interference. Clim Dyn 42:159-170

Taguchi M, Hartmann DL (2006) Increased occurrence of stratospheric sudden warmings during El Niño as simulated by WACCM. J Clim 19:324-332

Wang C (2002) Atlantic climate variability and its associated atmospheric circulation cells. J Clim 15:1516-1536

Willmott CJ, Matsuura K (2001) Terrestrial air temperature and precipitation: monthly and annual time series (1950-1999), https ://www.esrl.noaa.gov/psd/data/gridded/data.UDel_AirT_Preci p.html\#detail. Accessed Apr 2015

Woo S-H, Sung M-K, Son S-W, Kug J-S (2015) Connection between weak stratospheric vortex events and the Pacific Decadal Oscillation. Clim Dyn 45:3481-3492

Yu J-Y, Kim ST (2011) Relationships between extratropical sea level pressure variations and the Central Pacific and Eastern Pacific types of ENSO. J Clim 24:708-720

Yu J-Y, Lu M-M, Kim ST (2012) A change in the relationship between tropical central Pacific SST variability and the extratropical atmosphere around 1990. Environ Res Lett 7:034025. https://doi. org/10.1088/1748-9326/7/3/034025

Zhang R, Delworth TL (2007) Impact of the Atlantic Multidecadal Oscillation on North Pacific climate variability. Geophys Res Lett 34:L23708. https://doi.org/10.1029/2007GL031601

Zubiaurre I, Calvo N (2012) The El Niño-Southern Oscillation (ENSO) Modoki signal in the stratosphere. J Geophys Res 117:D04104. https://doi.org/10.1029/2011JD016690 